\title{
Hepatoprotective Potential of Methanolic and Aqueous Extract of Chenopodium botrys against Lead-induced Toxicity
}

\author{
Nidhi Gupta', Rakesh Sagar ${ }^{2}$, Mohan Lal Kori ${ }^{3, *}$ \\ Department of Pharmacology, Sri Sathya Sai Institute of Pharmaceutical Sciences, RKDF University, Bhopal, Madhya Pradesh, INDIA \\ ${ }^{2}$ Department of Pharmacognosy, Shri G.S. Institute of Technology and Science, Indore, Madhya Pradesh, INDIA. \\ ${ }^{3}$ Department of Pharmacognosy, Vedica College of B Pharmacy, RKDF University, Bhopal, Madhya Pradesh, INDIA.
}

\begin{abstract}
Background: Chenopodium botrys L. is local to Europe and Asia and established in North America. The plant commonly used for the treatment of disease. The medicinal use of Chenopodium botrys is mainly due to mythology rather than scientific proof. Objectives: To evaluate the hepatoprotective potential of methanolic and aqueous extract of Chenopodium botrys against lead-induced toxicity. Materials and Methods: The aerial parts of Chenopodium botrys were extracted by the continuous hot extraction process using acetone and methanol as a solvent and the aqueous extract of the plants were obtained by the cold maceration process. Liver tissue was treated with $5 \mathrm{ppm}$ Lead Acetate and $5 \mathrm{mg} / \mathrm{ml}$ of acetone methanol and aqueous extract of Chenopodium botrys. During the study, biochemical indices like lipid peroxidation (LPO), Protein levels and enzymatic activities of alkaline phosphatase (ALPase), acid phosphatase (ACPase) and succinate dehydrogenase (SDH) were measured. Results: The current study report that protein levels and enzymatic parameters of alkaline phosphatase as well as succinate dehydrogenase declined significantly while levels of lipid peroxidation and acid phosphatase increased significantly in lead acetate exposed goat liver homogenates as compared
\end{abstract}

to control groups. Co-administration of herbal methanol and aqueous extract of Chenopodium botrys $(5 \mathrm{mg} / \mathrm{ml}$ ) along with $5 \mathrm{ppm}$ lead acetate to liver homogenate exerted an ameliorative effect and maintained the studied parameters closed to control group. Conclusion: Chenopodium botrys is endowed with hepatoprotective activity. It can be taken as one candidate for the development of hepatoprotective agents because of its good safety profile.

Key words: Chenopodium botrys L., Traditional uses, Lead Toxicity, Hepatoprotective, Goat.

Correspondence

Dr. Mohan Lal Kori,

Vedica College of Pharmacy, RKDF University, Bhopal, Madhya Pradesh, INDIA. ORCID- orcid.org/0000-0003-2899-7781

Email id: nidhigupta25may@gmail.com;

DOI: 10.5530/ijpi.2021.2.30

\section{INTRODUCTION}

The genus Chenopodium comprises numerous members of perennial and annual species, which occur everywhere in the world. They could grow as aromatic or non-aromatic herbaceous plants or as shrubs and small trees. ${ }^{1}$ C. botrys L. (syn. Dysphania botrys (L.) Mosyakin and Clemants), known as Jerusalem Oak Goosefoot or Feathered Geranium, commonly grows in Europe and is native to Mediterranean region, but it also could be found in Asia, India, Himalayas, Turkey, Cyprus, Africa, Australia and North and South America. ${ }^{2}$ The plant is known as traditional medicine for different ailments in respiratory tract, especially for the treatment of acute rhinitis and respiratory disorder. and it is used as an alternative of C. ambrosioides. ${ }^{3}$ On the basis of a literature survey it is conclude that C. botrys contains flavonoids, alkaloids, terpenes and essential oil. ${ }^{4}$ C. botrys oil contains distinct number of isomers of monoterpene, ascaridole, were found in the C. botrys oil which was used in the treatment of tumor cell lines in vitro. ${ }^{5}$ Additionally, in the aerial parts of C. botrys, the flavon chrysoeriol as well as flavonoids: salvigenin, sinensetin, hispidulin, quercetin and their derivatives were identified, which were related to a potential antioxidant activity. ${ }^{4}$

In the flora of the Republic of Macedonia (RM), 15 species of the genus Chenopodium occur naturally, including C. botrys. ${ }^{6}$ Dried over ground flowering parts of the plant (herba) are utilized by local people for preparing infusions or liquid extracts with diuretic antispasmodic, carminative and antidiarrheal properties. ${ }^{7}$ Despite its usage, chemical composition and biological activity of this plant are poorly known.

Chenopodium botrys $(\mathrm{Cb})$ is a strongly aromatic medicinal plant growing in Jaunsar-Bawar, a hilly tribal inhabited area in Uttar Pradesh, India and in dry sandy areas in the temperate Himalayas from Kashmir to Sikkim. ${ }^{8}$ Chenopodium botrys $(\mathrm{Cb})$ finds use in multiple therapeutic applications such as expectorant, anticonvulsant, antibacterial, and tonic. ${ }^{9}$ In Kashmir Himalayas, an ethnomedicinal survey indicates that the seed decoction of the plant is used relieves a headache due to gallbladder troubles, for treating tapeworm infestation in children ${ }^{10}$ anthelmintic, diuretic, liver diseases, and laxative. ${ }^{11}$ In Tibetan medicine, $\mathrm{Cb}$ is used to treat stomach and liver problems. ${ }^{12}$ During an ethnomedicobotanical survey of Jaunsar-Bawar, a hilly tribal inhabited area in Uttar Pradesh, India; it was observed that about 100 plants are being used by the local Jaunsari tribe for the treatment of various ailments.

Keeping this perspective in mind, investigation of the possible therapeutic role of Chenopodium botrys as a protective agent against lead-induced hepatic toxicity is necessary. The objective of study was to understand the mechanism of lead toxicity on various biochemical changes such as alterations in lipid peroxidation, protein content and enzyme activities in goat liver homogenate in order to avoid the ethical concern of involving experimental animals. Another objective of the current study was to 
explore a substance which will help in the treatment of lead toxicity with maximum beneficial effect and less adverse effect.

\section{MATERIALS AND METHODS}

\section{Collection of Plant materials}

The aerial parts of Chenopodium botrys were collected in the month of August from Jaunsar-Bawar, hills, Uttar Pradesh and were Identified and authenticated by taxonomists.

\section{Chemicals}

The analytical reagent (AR) grade lead acetate trihydrate having 99\% purity was obtained from HIMEDIA Laboratory Pvt. Ltd., Mumbai, India. All the other chemicals of AR grade used in the present study were procured from Sigma and Merck Laboratory Pvt. Ltd., India. The acetone and methanol extract of the plants were obtained by the continuous hot extraction process. And the aqueous extract of the plants were obtained by the cold maceration process.

\section{Experimental design ${ }^{13}$}

In the present study, experimental protocol was designed into two separate phases. During the first phase, goat liver homogenate cultures were exposed for the specific period of time to different concentrations of lead acetate selected on the basis of $\mathrm{LD}_{50}$ value and reported literature in order to evaluate the lead-induced alterations in selected biochemical parameters like lipid peroxidation, protein content and enzymatic activities of alkaline phosphatase, acid phosphatase as well as succinate dehydrogenase in vitro. The second phase involves co-administration of acetone, methanol and aqueous extract of Chenopodium botrys to lead acetate exposed homogenate for specific time duration to investigate an ameliorative effect of the antidote against lead toxicity.

\section{Preparation of plant extract}

$10 \mathrm{ml}$ of distilled water was used to dissolve $100 \mathrm{mg}$ of crude acetone, methanol and aqueous extract of Chenopodium botrys.

\section{Preparation of lead acetate solutions}

The $100 \mathrm{ppm}$ of stock solution of lead acetate was prepared by adding $0.010 \mathrm{gm}$ of lead acetate in $100 \mathrm{ml}$ of distilled water. Final concentration used in the experiment are $1 \mathrm{ppm}, 3 \mathrm{ppm}$ and $5 \mathrm{ppm}$ concentrations of lead acetate.

\section{Sample collection}

After sacrificing the goat Capra hircus. The liver sample of 250-350 gm was collected from the local market. The fresh liver tissue was brought to the lab under frozen condition and used immediately. The appearance of fresh tissue was dark reddish-brown color. Liver tissue was washed in normal saline, blotted dry by pressing between 2-3 folds of filter paper and divided into different experimental groups.

\section{In vitro study}

The experimental protocol for in vitro study on hepatoprotective effect of Chenopodium botrys against lead-induced toxicity includes ten experimental groups:

(I) Control Group

(II) Acetone extract of Chenopodium botrys $(5 \mathrm{mg} / \mathrm{ml})$ Exposed Group

(III) Methanol extract of Chenopodium botrys $(5 \mathrm{mg} / \mathrm{ml})$ Exposed Group
(IV) Aqueous extract of Chenopodium botrys $(5 \mathrm{mg} / \mathrm{ml})$ Exposed Group

(V) Low Dosage 1ppm Lead Acetate Group

(VI) Mid Dosage 3 ppm Lead Acetate Group

(VII) High Dosage 5 ppm Lead Acetate Group

(VIII) $5 \mathrm{ppm}$ Lead Acetate $+5 \mathrm{mg} / \mathrm{ml}$ acetone extract of Chenopodium botrys

(IX) $5 \mathrm{ppm}$ Lead Acetate $+5 \mathrm{mg} / \mathrm{ml}$ methanol extract of Chenopodium botrys

(X) $5 \mathrm{ppm}$ Lead Acetate $+5 \mathrm{mg} / \mathrm{ml}$ aqueous extract of Chenopodium botrys

The sample of various lead and extract group was proceed to the process of homogenization with constant speed and temperature of $4^{\circ} \mathrm{C}$ in mortar pestles made up of glass. The color of the tissue changes to whitish red after haemolysis. All the group containing lead and extract together homogenate for time interval of $30 \mathrm{~min}$. The other group as well as exposed group were maintained at same conditions in $5 \% \mathrm{CO}_{2}$ containing $\mathrm{BOD}$ incubator at $37^{\circ} \mathrm{C}$ and subjected to study of various biochemical indices for investigating ameliorative effect of the antidote against leadinduced hepatotoxicity.

\section{Biochemical analysis}

To analyze free radical induced cell injury by lead acetate, the levels of lipid peroxides were determined in liver homogenates. The measurement of lipid peroxidation (LPO) in the liver homogenates of control and exposed groups were done by the method of Ohkawa. ${ }^{14}$ A $10 \%$ of tissue homogenate of liver was prepared in ice cold $0.1 \mathrm{M}$ phosphate buffer solution $(\mathrm{pH}=7.4)$ for the estimation of lipid peroxidation levels. For investigation of toxic effect of lead acetate on the protein metabolism, levels of soluble proteins were estimated in goat liver homogenates by the method of Lowery. ${ }^{15}$ At the end of the lead acetate treatment as well as Chenopodium botrys exposure, certain specific parameters of goat liver, including enzyme activities of alkaline phosphatase, acid phosphatase and succinate dehydrogenase were also investigated. The alkaline phosphatase and acid phosphatase activities were analyzed by the method of Besse ${ }^{16}$ while the Beatty ${ }^{17}$ method was used to measure the activity of succinate dehydrogenase. $0.1 \mathrm{gm}$ of liver tissue was homogenized in the known amount of double distilled water for the estimation of soluble proteins, alkaline phosphatase, acid phosphatase and succinate dehydrogensase activities.

\section{Statistical analysis}

Student's' $t$ - test' was used for the statistical analysis of the data. For each parameter $(n=5)$, the data were expressed as mean \pm SEM after subjecting to Student's ' $t$ - test' using GraphPad software for the interpretation of results. The significance difference was statistically considered at the level of $p<0.05$.

\section{RESULTS}

\section{Hepatoprotective effect of Chenopodium botrys Lipid peroxidation}

Results of the LPO in the goat liver homogenate exposed to different concentrations of lead acetate, Chenopodium botrys extracts and related control in vitro are given in Table 1. Their percentage of difference, due to the lead acetate and extracts exposure with respect to their control, is given in Table 2. As the concentration of lead increases the lipid peroxidation also increases due to the formation of thiobarbituric acid substance. Lipid peroxidation at low dosage (1 ppm) and medium dosage (3 ppm) and high dose of 5ppm exposure was represented as $6.74 \%$ $(p<0.05), 20.92 \%(p<0.01)$ and $35.10 \%(p<0.001)$ respectively. However, 
the lead acetate ( $5 \mathrm{ppm}$ ) along with the acetone, methanol and aqueous extract $(5 \mathrm{mg} / \mathrm{ml})$ in goat liver homogenate significantly reduced to $24.34 \%$, $25.84 \%$, and $25.71 \%$ respectively. Supplementation of methanol and aqueous extract of Chenopodium botrys as an ameliorative agent resulted in significant reduction in elevated MDA (Malondialdehyde) levels in lead exposed group.

\section{Protein levels}

Lead acetate exposure caused the significant decline in the protein levels in goat liver homogenates compared to control (Table 1). The decrease in the protein content at $1 \mathrm{ppm}$ and $3 \mathrm{ppm}$ exposure was represented as $17.53 \%(p<0.02)$ and $26.66 \%(p<0.001)$, respectively. Maximum reduction of protein content $35.49 \%$ in the liver homogenate was observed at $5 \mathrm{ppm}$ concentration of lead acetate $(p<0.001)$. Administration of acetone methanol and aqueous extract of Chenopodium botrys $(5 \mathrm{mg} / \mathrm{ml})$ to homogenate did not cause any significant effect. However, simultaneous supplementation of lead acetate $(5 \mathrm{ppm})$ and Chenopodium botrys acetone methanol and aqueous extract $(5 \mathrm{mg} / \mathrm{ml})$ in liver homogenate significantly increased $43.19 \%, 54.28 \%$ and $51.00 \%$ respectively protein level compared to lead acetate (5 ppm) exposed group (Table 2). Supplementation of methanol and aqueous extract of Chenopodium botrys as a therapeutic agent resulted in significant maintenance of protein levels against lead intoxication.

\section{Alkaline phosphatase (E.C.3.1.3.1) [E.C. - Enzyme Commission Number]}

Lead acetate exposure to goat liver homogenate for $30 \mathrm{~min}$ brought about a significant reduction in the alkaline phosphatase activity. Results revealed that alkaline phosphatase activity markedly decreased as the dose of lead acetate was increased in goat liver homogenate, and it remained less than control always (Table 1$)$. The decline in the enzyme activity at $1 \mathrm{ppm}$ and $3 \mathrm{ppm}$ exposure was represented as $57.19 \%(p<0.01)$ and $59.42 \%(p<0.01)$, respectively. Maximum retardation of enzyme activity $63.58 \%$ in liver homogenate was noted at 5 ppm exposure of lead acetate $(p<0.001)$. Addition of $5 \mathrm{mg} / \mathrm{ml}$ acetone methanol and aqueous extract of Chenopodium botrys to homogenate did not cause any significant effect. However, simultaneous addition of the lead acetate (5 ppm) and acetone methanol and aqueous extract of Chenopodium botrys $(5 \mathrm{mg} / \mathrm{ml})$ in goat liver homogenate significantly maintained $4.79 \%, 0.96 \%$ and $1.60 \%$ reduction in enzyme activity as compared to control (Table 2). Supplementation of methanol and aqueous extract of Chenopodium botrys significantly maintained alkaline phosphatase activity closest to control group and exerted protective effect against lead toxicity.

\section{Acid phosphatase (E.C.3.1.3.2)}

Results revealed that acid phosphatase activity significantly increased as the dose of lead acetate was increased in goat liver homogenate (Table 1). The increase in the enzyme activity at $1 \mathrm{ppm}$ and $3 \mathrm{ppm}$ lead exposure in homogenate cultures was represented as $2.21 \%(p<0.0001)$ and $10.87 \%$ $(p<0.0001)$, respectively. Statistically extremely significant elevation of $p<0.000129 .83 \%$ of enzyme activity in liver homogenate was observed at $5 \mathrm{ppm}$ concentration of lead acetate. Addition of $5 \mathrm{mg} / \mathrm{ml}$ acetone methanol and aqueous extract of Chenopodium botrys to homogenate did not cause any significant effect. However, simultaneous addition of lead acetate $(5 \mathrm{ppm})$ and acetone methanol and aqueous extract of Chenopodium botrys $(5 \mathrm{mg} / \mathrm{ml})$ in goat liver homogenate significantly ameliorated $8.09 \%, 22.70 \%$ and $18.16 \%$ respectively the enzyme activity (Table 2). Addition of methanol and aqueous extract of Chenopodium botrys as the therapeutic agent significantly maintained acid phosphatase activity in lead exposed liver homogenate nearest to control group.

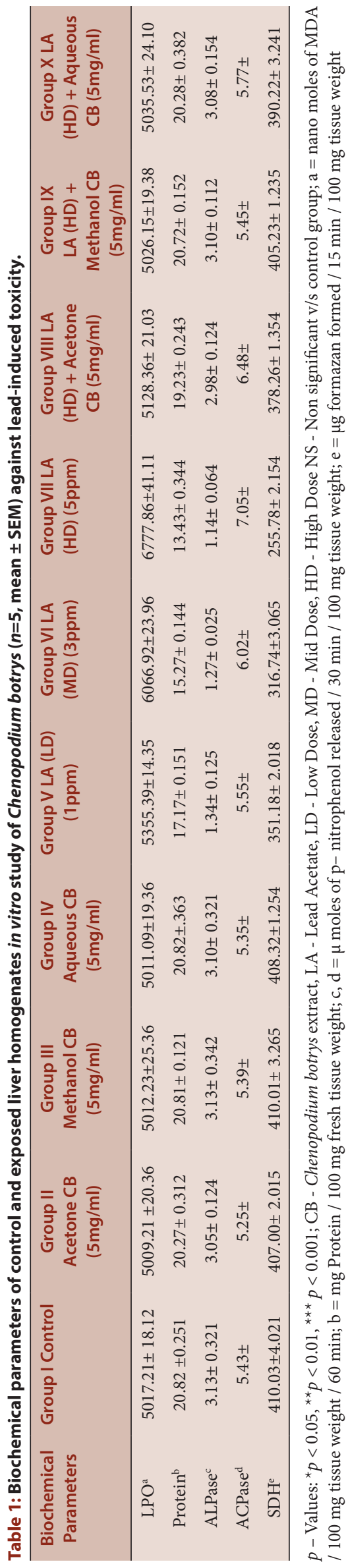


Table 2: Gross effect of lead and Chenopodium botrys (CB) on biochemical parameters of goat liver homogenates in vitro (\% of difference with respect to their control as well as lead exposed homogenate cultures).

\begin{tabular}{|c|c|c|c|c|c|c|c|c|c|}
\hline $\begin{array}{l}\text { Biochemical } \\
\text { Parameters }\end{array}$ & $\begin{array}{l}\text { Group V LA } \\
\text { (LD) (1 ppm) }\end{array}$ & $\begin{array}{l}\text { Group VI LA } \\
\text { (MD) (3ppm) }\end{array}$ & $\begin{array}{l}\text { Group VII LA } \\
\text { (HD) (5ppm) }\end{array}$ & $\begin{array}{l}\text { Group VIII } \\
\text { LA (HD) + } \\
\text { Acetone CB } \\
\text { (5mg/ml) } \\
\text { (a) }\end{array}$ & $\begin{array}{l}\text { Group IX } \\
\text { LA (HD) + } \\
\text { Methanol CB } \\
(5 \mathrm{mg} / \mathrm{ml}) \\
\text { (a) }\end{array}$ & $\begin{array}{l}\text { Group X } \\
\text { LA (HD) + } \\
\text { Aqueous CB } \\
\text { (5mg/ml) } \\
\text { (a) }\end{array}$ & $\begin{array}{l}\text { Group VIII } \\
\text { LA (HD) + } \\
\text { Acetone CB } \\
\text { (5mg/ml) } \\
\text { (b) }\end{array}$ & $\begin{array}{l}\text { Group IX } \\
\text { LA (HD) + } \\
\text { Methanol CB } \\
(5 \mathrm{mg} / \mathrm{ml}) \\
\text { (b) }\end{array}$ & $\begin{array}{l}\text { Group X } \\
\text { LA (HD) + } \\
\text { Aqueous CB } \\
(5 \mathrm{mg} / \mathrm{ml}) \\
\text { (b) }\end{array}$ \\
\hline $\mathrm{LPO}^{\mathrm{a}}$ & 6.74 & 20.92 & 35.10 & 2.22 & 0.18 & 0.37 & 24.34 & 25.84 & 25.71 \\
\hline Protein $^{\mathrm{b}}$ & 17.53 & 26.66 & 35.49 & 7.64 & 0.48 & 2.59 & 43.19 & 54.28 & 51.00 \\
\hline $\mathrm{SDH}^{\mathrm{e}}$ & 14.35 & 22.75 & 37.62 & 7.75 & 1.17 & 4.83 & 47.88 & 58.43 & 52.56 \\
\hline
\end{tabular}

All values are expressed in \% of decrease or increase; a - compared to control group; b - compared to Group VII

\section{Succinate dehydrogenase (E.C.1.3.99.1)}

A significant decline was observed in the activity of succinate dehydrogenase in lead exposed homogenate cultures compared to control (Table 1). Reduction in enzyme activity at low dosage (1 ppm), medium dosage (3 ppm), and high dosage (5 ppm) exposure was represented as 14.35 $\%(p<0.001), 22.75 \%(p<0.001)$ and $37.62 \%(p<0.001)$, respectively. Administration of acetone methanol and aqueous extract of Chenopodium botrys to homogenate did not cause any significant effect. However, co-administration of lead (5 ppm) and acetone methanol and aqueous extract of Chenopodium botrys $(5 \mathrm{mg} / \mathrm{ml})$ in liver homogenate significantly ameliorated $47.88 \%, 58.43 \%$ and $52.56 \%$ respectively succinate dehydrogenase activity as compared to lead ( $5 \mathrm{ppm}$ ) exposed group (Table 2) and methanol and aqueous extract of Chenopodium botrys exerted protection against lead-induced hepatotoxicity.

\section{DISCUSSION}

During the in vitro study the Malondialdehyde level was found to be elevated in the lead group and the level in control group was normal as compared to lead group. The rise in the level of MDA was due to the formation of reactive oxygen called as free radicals. The imbalance between antioxidant system and free radicals leads to oxidative stress. According to the previous literature the mechanism behind the increase in the formation of free radicals are hydroxyl radicals, hydrogen peroxide and superoxide ions are responsible for the decrease of scavenger glutathione.

The in vitro investigation shows that the addition of methanol and aqueous extract of Chenopodium botrys to the lead group of various concentrations shows a tremendous decrease in the lipid peroxides and protein content level in the goat liver homogenates. The active phytoconstituents present in the methanol and aqueous extract of Chenopodium botrys shows a beneficial effect in decreasing the free radicals.

The lowering of protein level is due to combining of lead and sulfhydryl group containing protein and various enzymes interfere in this process which plays a vital role in the cell metabolism. Further, at the time of lipid peroxidation Malondialdehyde was manufacture which attaches to -SH groups of protein and show a harmful effect. Thus inhibiting enzymes requiring - $\mathrm{SH}$ groups for their activities. ${ }^{18}$ The reduction of protein level is due to proteolysis and the reduced incorporation of amino acids into proteins ${ }^{19}$ or increased deamination of amino acids in the liver and kidney. Thus, one of the reasons for liver toxicity in the current study might be the decreased availability of proteins necessary for growth and differentiation of tissues and enzyme systems.
The methanol and aqueous extract of Chenopodium botrys is able to prevent cell injury by maintaining sulfhydryl groups of membrane binding proteins. The hepatoprotective and membrane stabilizing properties of the plant can be attributed to its anticholestic action, reduction in free radicals and reduction in cell protein necrosis as well as glutathione depletion reduction potential.

Many products of LPO such as hydro peroxides can inhibit protein synthesis and alter enzyme activity. ${ }^{20}$ Results of current study elucidated that lead acetate exposure caused significant depletion in activity of alkaline phosphatase in liver. Alkaline phosphatases are a group of enzymes, which hydrolyze phosphate esters at alkaline $\mathrm{pH}$. Reduced alkaline phosphatase activity might be attributed to the alteration in cell membrane permeability in addition to lead-induced imbalance between synthesis and degradation of enzyme.

The data of current investigation also revealed the increase in acid phosphatase activity in lead acetate exposed liver homogenates. Acid phosphatase, a lysosomal enzyme is involved in a number of activities such as phagocytosis, ${ }^{21}$ autolysis, and dissolution of tissue components, fat absorption in intestine; cellular differentiation and keratinization. ${ }^{22}$ Alteration in activity might be due to direct inhibitory effect of accumulated lead and fat as well as disturbed balance between synthesis and degradation of enzyme in liver.

Results shows that liver homogenate with lead acetate group lost the $\mathrm{SDH}$. The changes occur due to the change in the metabolism occur during TCA cycle which affect the conversion of succinate to fumarate which block the Kreb's cycle that will result in decrease in the production of ATP. Changes in the SDH activity is also due to changes in mitochondrial structure and functions of mitochondrial enzymes due to accumulation of lead in mitochondria. Lead may uncouple oxidative phosphorylation, which may reflect on the slow rate of TCA cycle. Thus, lowering of SDH activity shows the altered state of oxidation and energy metabolism of a damaged liver.

The methanol and aqueous extract Chenopodium botrys also manifested maintenance of alkaline phosphatase, acid phosphatase and succinate dehydrogenase enzyme activities in goat liver homogenate nearest to control.

\section{CONCLUSION}

In conclusion, the findings of present study suggest the role of oxidative mechanisms in lead-acetate induced liver damage. From the current in vitro study, it can be clearly elucidated that heavy metal lead affects the antioxidative as well as other biochemical indices of goat liver possibly by inducing oxidative stress. Present research study also suggested that 
lead metal appears to cause an imbalance in the antioxidant defense system by inhibiting some related enzymes, thereby enhancing the free radical mediated peroxidation of lipids. The study findings also confer that lead adversely affects the protein content as well as energy and oxidative metabolism of goat liver. Thus, from the present in vitro study, it can be clearly concluded that lead exposure has a definitely destructive effect on the structural, metabolic and functional status of liver.

The current investigation also emphasized that co-administration of methanol and aqueous extract of Chenopodium botrys in liver homogenate significantly exerts protective effects against lead intoxication due to the presence of flavonoids and phenolic compounds. Thus, it is clearly revealed that Chenopodium botrys has a significant role in alleviating the lead toxicity. It acts as a therapeutic eliminator of heavy metals. Hence, this antidote could be a very effective and beneficial ameliorating agent against lead-induced hepatic toxicity the world over.

The present investigation has elucidated the mechanism of action of lead-induced hepatotoxicity and also suggested its amelioration, which can be considered as a significant contribution in the field of mitigation of plumbism in endemic regions.

\section{ACKNOWLEDGEMENT}

The authors would like to thank RKDF University, Bhopal Madhya Pradesh, India for providing the required facilities for research work.

\section{CONFLICT OF INTEREST}

The authors declare no conflict of interest.

\section{ABBREVIATIONS}

LPO: Lipid peroxidation; ALPase: Alkaline phosphatase; ACPase: Acid phosphatase; SDH: Succinate dehydrogenase; TCA cycle: Tricarboxylic acid cycle.

\section{REFERENCES}

1. Fuentes-Bazan $S$, Uotila P, Borsch T. A novel phylogeny-based generic classification for Chenopodium sensu lato, and a tribal rearrangement of Chenopodioideae (Chenopodiaceae). Willdenowia. 2012;42(1):5-24. doi: 10.3372/wi.42.42101.

2. Seidemann J. World Sspice Pplants: Eeconomic Uusage, Bbotany, Ttaxonomy. Vol. VIII. Berlin, Heidelberg: Springer, VIII,; 2005;. p. 592-593.

3. Yadav N, Vasudeva N, Singh S, Sharma SK. Medicinal properties of genus Chenopodium Linn. Nat Prod Rad. 2007; 6:131-134.

4. Kokanova-Nedialkova Z, Nedialkov P.T, Nikolov S.D. The genus Chenopodium: Pphytochemistry ethnopharmacology and pharmacology. Pharmacogn Rev. 2009;3:280-306
5. Morteza-Semnani K. A Review on Chenopodium botrys L.: traditional uses, chemical composition and biological activities. Pharm Biomed Res. 2015;1(2):19. doi: 10.18869/acadpub.pbr.1.2.1.

6. Micevski K. Flora of the Rrepublic of Macedonia. Skopje: Macedonian Academy of Science and Art, Skopje, Republic of Macedonia.; 1995.

7. Maksimovic Z.A, Đordevic S, Mraovic M. Antimicrobial activity of Chenopodium botrys essential oil. Fitoterapia. 2005;76(1):112-4. doi: 10.1016/j.fitote.2004. 10.005, PMID 15664473.

8. Nadkarnin KM. Indian Mmateria medica: Wwith Aayurvedic, Una ni-Tibbi, Siddha, Aallopathic, Nomeopathic, Nnaturopathic and Hhome Rremedies, Aappendices and lindexes. 1. $3^{\text {rd }}$ ed. Vol. 1. New Delhi: Popular Press Prakashan.; 1996.

9. Zargari A. Medicinal Pplants. $6^{\text {th }}$ ed. Vol. 1. Tehran: Tehran University Publications. Tehran: Tehran University Publications.; 1993.

10. Singh V. Herbal remedies for worm infestation in Kashmir Himalaya. Fitotherapia. 1994;65:354-6.

11. Koul MK. Medicinal plants of Kashmir and Ladakh. New Delhi: Indus Publishing Company.; 1997.

12. Singh V, Kapahi BK, Srivastava TN. Medicinal herbs of Ladakh especially in home ramedies. Fitotherapia. 1996;67:38-48.

13. Shah C. Flora SC and, Jain K. Nayan JK. In vitro Study on Hhepatoprotective Effect of Phyllanthus fraternus Against Lead Induced Toxicity. UK J Pharm Biosci. 2016;4(2):31-7.

14. Ohkawa $H$, Ohishi N, Yagi K. Assay for lipid peroxidation in animal tissues by thiobarbituric acid reaction. Anal Biochem. 1979;95(2):351-8. doi: 10.1016/00032697(79)90738-3, PMID 36810.

15. Lowery $\mathrm{OH}$, Rosebrough NJ, Farr AL, Randall RJ. Protein measurement with folin-phenol reagent. J Biochem. 1951;193:265-75

16. Bessey OA, Lowry OH, Brock MJ. A method for the rapid determination of alkaline phosphates with five cubic millimeters of serum. J Biol Chem. 1946;164:321-9. doi: 10.1016/S0021-9258(18)43072-4. PMID 20989492.

17. Beatty $\mathrm{CH}$, Basinger GM, Dully CC, Bocek RM. COMPARISON OF RED AND WHITE VOLUNTARY SKELETAL MUSCLES OF SEVERAL SPECIES OF PRIMATES. J Histochem Cytochem. 1966;14(8):590-600. doi: 10.1177/14.8.590.

18. Halliwell B, and Gutteridge JM. Oxygen toxicity, oxygen radicals, transition metals and disease. Biochem J. 1984;219(1):1-14. doi: 10.1042/bj2190001, PMID 6326753

19. Shashi A, Thapar SP and, Singh JP. Effects of fluoride administration on organs of gastrointestinal tract-an exp. study on rabbits-Effects on tissue proteins. study on rabbits-Effects on tissue proteins. Fluoride. 1987;20(3):183-8.

20. Esterbauer $\mathrm{H}$. Lipid peroxidation products formation, Chemical properties and biological activities. In: Poli G, Cheesman KH, Dianzani MV and, Slater TF, editors. Free radical in liver injury. Oxford,: IRL Press Ltd.; 1986:29-45.

21. Klockars $M$ and, Wegelius $O$. Lysosomal enzymes in regenerating rat liver. Proc Soc Exp Biol Med. 1969;131(1):218-22. doi: 10.3181/00379727-131-33844, PMID 5770106

22. World Health Organization (WHO). IPCS International Programme on Chemica Safety. Environmental Hhealth Crieteria-36. Published by United Nations Environment Programmme, the International Labour Organization, and the World Health Organization. Published by United Nations Environment Programmme the International Labour Organization, and the World Health Organization, Geneva. 1984;1-136.

Article History: Submission Date : 01-05-2021; Revised Date : 29-05-2021; Acceptance Date : $19-06-2021$.

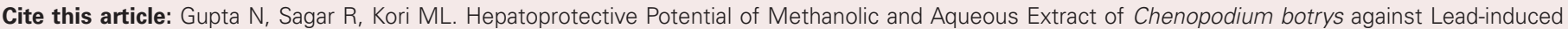
Toxicity. Int. J. Pharm. Investigation. 2021;11(2):165-9. 